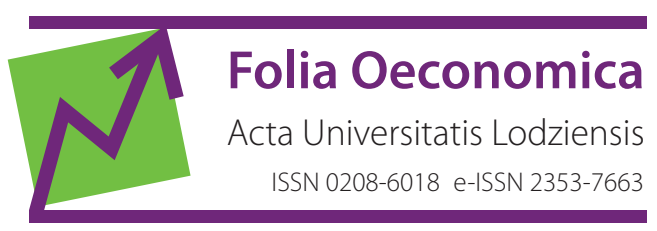

www.czasopisma.uni.lodz.pl/foe/

3(342) 2019

DOI: http://dx.doi.org/10.18778/0208-6018.342.11

\title{
Katarzyna Mokrzycka
}

Uniwersytet Ekonomiczny w Krakowie

mokrzyck@uek.krakow.pl

\section{Użyteczność mierników oceny kondycji finansowej w szpitalnictwie na przykładzie wybranych województw}

\begin{abstract}
Streszczenie: Działalność biznesowa jednostek medycznych oceniana jest na podstawie zasobów ekonomicznych, które pozwalają na dokonanie oceny efektywności badanego podmiotu gospodarczego. Zestaw miar i wskaźników analitycznych jest pomocny w ocenie kondycji finansowej badanej instytucji medycznej. Artykuł ma na celu dokonanie oceny użyteczności mierników kondycji finansowej jednostek medycznych w trzech wybranych województwach: podkarpackim, małopolskim i lubelskim w latach 2014-2016. Aby móc osiągnąć cel, zastosowano źródła niezbędne w analizie wskaźników instytucji. Praca zawiera przegląd popularnych polskich modeli analizy dyskryminacyjnej w zakresie prognozowania bankructwa jednostek medycznych. Zmiany otoczenia gospodarczego wpływają na bieżącą kondycję finansową i zdolność do kontynuowania działalności. Trafność prognoz bankructwa w znacznym stopniu zależy od szybko zmieniającego się otoczenia zewnętrznego. Wnioskiem z przeprowadzonych rozważań może być stwierdzenie, że w procesie prognozowania bankructwa nie można opierać się tylko na wskaźnikach finansowych z przeszłości, można je modyfikować zmiennymi czasowymi wskazującymi na stan koniunktury.
\end{abstract}

Słowa kluczowe: analiza wskaźnikowa, analiza dyskryminacyjna, analiza wielowymiarowa, sprawozdanie finansowe jednostek medycznych, wskaźniki finansowe

JEL: M40, M41 


\section{Wprowadzenie}

Szpital to zakład opieki zdrowotnej realizujący dwa zasadnicze cele. Pierwszy z nich - społeczny - oznacza gotowość przyjęcia i leczenia pacjenta, a także zapewnienia mu wykwalifikowanej opieki medycznej. Działalność szpitala nie jest nastawiona na maksymalizację zysku, jednak pojawiają się w niej kwestie ekonomiczne. Stąd też realizacja drugiego celu, jakim jest dążenie do utrzymania płynności finansowej i rentowności. Działalność szpitali może być zatem oceniana na podstawie mierników ekonomicznych, dających informację o poziomie efektywności działalności badanego podmiotu oraz jego sytuacji majątkowej i finansowej. Instrumentarium niezbędnego do oceny sytuacji finansowej szpitalnictwa dostarcza analiza finansowa. Za pomocą zestawu mierników opisuje ona sytuację badanej jednostki z punktu widzenia jej rentowności, płynności oraz perspektyw dalszego rozwoju. Celem artykułu jest ocena użyteczności mierników kondycji finansowej jednostek medycznych w trzech wybranych województwach: podkarpackim, małopolskim i lubelskim w latach 2014-2016. W sytuacji braku przepisów i wytycznych obligujących do przeprowadzania analizy finansowej w szpitalnictwie można założyć, że wykorzystanie mierników jako instrumentów w szpitalach nie jest powszechnie praktykowane, mimo że w warunkach przeprowadzanych zmian w systemie ochrony zdrowia rola informacji finansowych jest decydująca.

\section{Ocena sytuacji finansowej zakładów opieki zdrowotnej w Polsce}

W warunkach gospodarki rynkowej ciągły i powtarzający się brak spłaty należności z tytułu zobowiązań przez dany podmiot będzie równoznaczny z jego upadłością. Inaczej sytuacja wygląda w samodzielnych zakładach opieki zdrowotnej, gdyż jako podmioty publiczne nie podlegają one regułom rynku, które dotyczą jednostek prywatnych. Samodzielność szpitali publicznych sprzyja zatem zachowaniom prowadzącym do zadłużania jednostek. Podejmowane są decyzje mające na celu oddłużanie szpitali, jednakże zadłużanie się jednostek publicznych oraz gromadzenie zobowiązań wymagalnych jest nadal bardzo poważnym problemem, ponieważ oddłużanie przeprowadzano bez zmiany mechanizmów prowadzących do tego procesu (Golimowska, 2008: 161). Wśród wielu przyczyn trudnej sytuacji finansowej jednostek służby zdrowia można wymienić następujące (Tuczapski, 2009):

1) niezbilansowanie przychodów z kosztami,

2) wzrost kosztów pracy,

3) brak określonej polityki udzielanych świadczeń zdrowotnych, 
4) niedofinansowanie procedur medycznych,

5) nieskoordynowane procedury zakupu sprzętu,

6) zakupy niepotrzebnego sprzętu,

7) bezczynność organów założycielskich,

8) nieefektywne wykorzystywanie prowadzonej działalności medycznej.

Istotnym wyróżnikiem sytuacji finansowej polskich jednostek medycznych jest zatem wysoki poziom zadłużenia, a głównie duży udział w zadłużeniu ogółem zobowiązań wymagalnych, oznaczających bezsporne zobowiązania, których termin płatności minął, ale nie są one przedawnione ani umorzone (Resort zdrowia, 20.02.2018). Trzeba zauważyć, że do zarządzania i oceny systemu ochrony zdrowia niezbędny jest system mierników.

System mierników i wskaźników w ochronie zdrowia musi być użyteczny w zmieniających się warunkach prawnych, organizacyjnych i finansowych ochrony zdrowia w Polsce. Można zatem stwierdzić, że użyteczność mierników nie budzi wątpliwości. Jednakże w systemie pomiaru należy uwzględnić zmiany równoległe do warunków na rynku usług medycznych, jakie wpływają na powstały system pomiaru i monitorowania, tak aby był on w najwyższym stopniu użyteczny i wspomagał ocenę stanu zarządzania w całym systemie czy też pojedynczym podmiocie. System powinien dostarczać informacji dających możliwość oceniania i zarządzania wieloma obszarami działalności placówek medycznych.

\section{System mierników i wskaźników w ochronie zdrowia}

System mierników i wskaźników w polskiej ochronie zdrowia można zaprezentować w trzech podstawowych zakresach (Hrynkiewicz, 2001: 8):

1) informacje służące do podejmowania decyzji:

- związane z kreowaniem polityki państwa oraz samorządów,

- dotyczące potrzeb, znaczenia i ich wartości dla realizacji zadań podmiotów ochrony zdrowia,

2) mierniki i wskaźniki pozwalające ocenić stan zdrowia społeczeństwa,

3) system finansowania ochrony zdrowia oraz pomiar wydatków:

- nakłady i wydatki na ochronę zdrowia,

- mechanizmy finansowania usług medycznych.

Przedstawione aspekty nie obejmują całego obszaru pomiarów w systemie ochrony zdrowia, gdyż kluczowym obszarem są mierniki i wskaźniki oceny działalności podmiotów. System miar i wskaźników jednostek medycznych może służyć do oceny osiąganych rezultatów, stopnia realizacji wytyczonych celów, wprowadzanych zmian. Mierniki mogą być zatem użyteczne w przypadku podjęcia 
próby oceny wpływu zmian systemowych w ochronie zdrowia na działalność prowadzonych podmiotów. Stworzenie i wprowadzenie systemu mierników i wskaźników daje możliwość monitorowania kosztów działalności placówek, a tym samym wpływania na wynik oraz racjonalizowane zużycie zasobów majątkowych. Mierniki i wskaźniki niezbędne do oceny sytuacji finansowej placówki medycznej pochodzą z analizy finansowej.

Analiza finansowa bada stan oraz rozwój szeroko pojętych finansów jednostek i finansowych skutków prowadzonej działalności. Daje możliwość badania w określonych horyzontach czasowych struktury i dynamiki majątku, kapitału, wyniku finansowego, kosztów i przepływów pieniężnych oraz ich relacji, obrazujących między innymi: płynność finansową, rentowność, zadłużenie i zdolność do obsługi długu oraz sprawność gospodarowania zasobami. Badania te prowadzone są w ujęciu retrospektywnym, lecz w miarę rozwoju wiedzy i technik obliczeniowych coraz częściej również w ujęciu prospektywnym (Wrzosek, 2006: 11). Do analizy efektywności finansowej mogą być stosowane różne metody, jednak w praktyce wykorzystywana jest metoda wskaźnikowa, mająca podstawowe znaczenie w syntetycznej ocenie sytuacji majątkowej i finansowej. Prawidłowo dobrany zestaw syntetycznych wskaźników obrazuje wzajemne relacje określonych wielkości ekonomicznych umożliwiających ocenę kondycji finansowej. Stosowanie w toku analizy syntetycznych wskaźników ułatwia ponadto ocenę efektywności finansowej podmiotu na tle efektywności branży oraz w stosunku do innych organizacji (Bień, 2005: 98-99).

\section{Narzędzia i źródła w ocenie sytuacji finansowej szpitala}

Analiza wskaźnikowa jest powszechnie znanym narzędziem oceny kondycji finansowej podmiotu gospodarczego. Za pomocą szerokiego wachlarza wskaźników można syntetycznie charakteryzować różne ekonomiczne aspekty działalności podmiotów. W krajach o gospodarce rynkowej wykorzystuje się zestawy podobnych pod względem treści wskaźników ekonomicznych. Ujednolicona treść wskaźników pozwala na jednoznaczną interpretację przez menedżerów, kredy todawców czy udziałowców. W zależności od grupy odbiorców analizy wskaźnikowej zakres wskaźników wykorzystywanych do analiz jest ograniczany lub rozszerzany (Sierpińska, Jachna, 1997: 78). Wskaźniki ekonomiczne ujmuje się w grupy o zbliżonej treści ekonomicznej.

Obszary analizy wskaźnikowej służą do oceny:

1) płynności finansowej,

2) rentowności, 
3) zadłużenia,

4) sprawności działania.

Najszerszy zakres wskaźników ekonomicznych jest wykorzystywany przez menedżerów podejmujących decyzje związane ze sprawnym działaniem jednostki. Użyteczność informacji pozyskiwanych z zastosowania wskaźników ekonomicznych jest zatem bezsporna. Do przeprowadzenia analizy wskaźnikowej sprawozdania finansowego wybranego jako podmiot badań w niniejszym artykule zostaną użyte wskaźniki zaprezentowane w Tabeli 1.

Formuły wskaźników sprawności działania wykorzystane do oceny działalności badanych województw zostały zaprezentowane w dalszej części artykułu. Źródłem oceny kondycji finansowej badanych jednostek szpitalnych jest sprawozdanie finansowe opublikowane w biuletynie Centralnego Systemu Informacji w Ochronie Zdrowia. Sprawozdawczość jest istotnym źródłem informacji o działalności gospodarczej każdej jednostki w danym okresie. W jednostkach opieki zdrowotnej, ze względu na źródła czy charakter informacji, wyróżnia się sprawozdawczość rzeczową oraz sprawozdawczość finansową. Dane sprawozdawczości rzeczowej związane są z problematyką organizacji procesu świadczenia usług medycznych, wielkością zasobów ludzkich i rzeczowych będących w dyspozycji ZOZ oraz działalnością tych zakładów. Jednostkowe sprawozdania statystyczne zawierają dane z dokumentacji medycznej indywidualnej (np. kart zdrowia, kart choroby) (Hass-Symotiuk, 2008: 657). Sprawozdawczość finansowa jest ostatnim etapem generowania informacji rachunkowych, a forma i treść informacji finansowych są określone przepisami prawa. Obowiązek sprawozdawczy jednostek szpitalnych, analogicznie jak w innych podmiotach gospodarczych, wynika z ustawy o rachunkowości.

Tabela 1. Wybrane wskaźniki analizy finansowej

\begin{tabular}{|c|c|}
\hline Wskaźnik & Formula \\
\hline \multicolumn{2}{|c|}{ Wskaźniki płynności finansowej } \\
\hline Wskaźnik płynności I & $\begin{array}{l}\text { aktywa obrotowe/zobowiązania } \\
\text { krótkoterminowe }\end{array}$ \\
\hline Wskaźnik płynności II & $\begin{array}{l}\text { (aktywa obrotowe - zapasy - RMK Cz.)/ } \\
\text { zobowiązania bieżące }\end{array}$ \\
\hline Wskaźnik płynności III & $\begin{array}{l}\text { inwestycje krótkoterminowe/zobowiązania } \\
\text { bieżące }\end{array}$ \\
\hline \multicolumn{2}{|c|}{ Wskaźniki rentowności } \\
\hline Wskaźnik rentowności majątku & wynik finansowy netto/aktywa ogółem \\
\hline Wskaźnik rentowności kapitału własnego & wynik finansowy netto/kapitał własny \\
\hline Wskaźnik rentowności netto sprzedaży & $\begin{array}{l}\text { wynik finansowy netto/przychody netto } \\
\text { ze sprzedaży }\end{array}$ \\
\hline Wskaźnik rentowności brutto sprzedaży & $\begin{array}{l}\text { wynik finansowy brutto/przychody netto } \\
\text { ze sprzedaży }\end{array}$ \\
\hline
\end{tabular}




\begin{tabular}{|c|c|}
\hline Wskaźnik & Formula \\
\hline Wskaźnik zaangażowanego kapitału & $\begin{array}{l}\text { wynik finansowy brutto + odsetki/kapitał } \\
\text { ogółem }\end{array}$ \\
\hline \multicolumn{2}{|c|}{ Wskaźniki zadłużenia } \\
\hline Wskaźnik ogólnego zadłużenia & zobowiązania/wartość majątku \\
\hline $\begin{array}{l}\text { Wskaźnik udziału kapitału własnego } \\
\text { w finansowaniu aktywów }\end{array}$ & kapitał własny/aktywa \\
\hline $\begin{array}{l}\text { Wskaźnik udziału zadłużenia w kapitale } \\
\text { własnym }\end{array}$ & zobowiązania/kapitał własny \\
\hline Wskaźnik zadłużenia długoterminowego & zobowiązania długoterminowe/kapitał własny \\
\hline Wskaźnik trwałości struktury finansowania & $\begin{array}{l}\text { kapitał własny + rezerwy + zobowiązania } \\
\text { długoterminowe/aktywa }\end{array}$ \\
\hline $\begin{array}{l}\text { Wskaźnik pokrycia majątku trwałego } \\
\text { kapitałem stałym }\end{array}$ & majątek trwały/kapitał stały \\
\hline \multicolumn{2}{|c|}{ Wskaźniki struktury majątku } \\
\hline $\begin{array}{l}\text { Wskaźnik pokrycia majątku trwałego } \\
\text { kapitałem własnym }\end{array}$ & (kapitał własny + rezerwy)/aktywa trwałe \\
\hline Trwałość struktury finansowania & $\begin{array}{l}\text { (kapitał własny + rezerwy + zobowiązania } \\
\text { długoterminowe)/suma pasywów }\end{array}$ \\
\hline Wskaźnik pokrycia straty zyskiem bieżącym & zysk bieżący/strata z lat ubiegłych \\
\hline Wskaźnik relacji straty do kapitałów własnych & strata skumulowana/kapitał własny \\
\hline \multicolumn{2}{|c|}{ Wskaźnik zadłużenia } \\
\hline Wskaźnik zadłużenia ogółem & zobowiązania ogółem/aktywa ogółem \\
\hline Wskaźnik długoterminowego zadłużenia & zobowiązania długoterminowe/aktywa ogółem \\
\hline Wskaźnik struktury zobowiązań & $\begin{array}{l}\text { zobowiązania długoterminowe/zobowiązania } \\
\text { ogółem }\end{array}$ \\
\hline Wskaźnik zadłużenia kapitałów własnych & zobowiązania ogółem/kapitał własny \\
\hline $\begin{array}{l}\text { Wskaźnik długoterminowego zadłużenia } \\
\text { kapitałów własnych }\end{array}$ & zobowiązania długoterminowe/kapitał własny \\
\hline \multicolumn{2}{|c|}{ Wskaźniki rotacji } \\
\hline Szybkość obrotu należności w dniach & $\begin{array}{l}\text { średni stan należności z tytułu dostaw i usług } \\
\text { x 365/przychody ze sprzedaży }\end{array}$ \\
\hline Szybkość spłaty zobowiązań w dniach & \begin{tabular}{|l|} 
średni stan zobowiązań z tytułu dostaw i usług \\
x 365/przychody ze sprzedaży
\end{tabular} \\
\hline Szybkość obrotu zapasów w dniach & $\begin{array}{l}\text { średni stan zapasów x 365/przychody } \\
\text { ze sprzedaży }\end{array}$ \\
\hline
\end{tabular}

Źródło: opracowanie własne na podstawie: Nowak, 2005: 165-188

Sprawozdanie finansowe zakładu opieki zdrowotnej obejmuje następujące elementy:

1) bilans,

2) rachunek zysków i strat,

3) informację dodatkową (wprowadzenie do sprawozdania finansowego oraz dodatkowe informacje i objaśnienia).

Jeżeli sprawozdanie finansowe ZOZ (szpitala) objęte jest obowiązkiem badania przez biegłego rewidenta, wówczas powstaje konieczność sporządzenia dodatkowo: 
1) rachunku przepływów pieniężnych,

2) zestawienia zmian w kapitale (funduszu) własnym.

W ocenie kondycji finansowej placówki medycznej ważna jest analiza wstępna struktury i dynamiki bilansu i rachunku wyników oraz jej dopełnienie - analiza wskaźnikowa. Oceny kondycji finansowej badanych województw dokonano na podstawie pięciu rodzajów mierników: płynności, rentowności, struktury majątku, rotacji, zadłużenia.

\section{Analiza finansowa jednostek medycznych w ujęciu zbiorczym w podziale na województwa}

Oceny sytuacji ekonomiczno-finansowej województw dokonano na podstawie wskaźników płynności finansowej. Do obliczenia poziomu wskaźników wykorzystano dane szpitala zawarte w bilansie oraz rachunku zysków i strat, niezaprezentowanych w artykule ze względu na ograniczenie objętości publikacji. Wskaźniki pozwalające na ocenę płynności finansowej przedstawiono w Tabeli 2.

Tabela 2. Wskaźniki płynności finansowej dla jednostek medycznych w ujęciu zbiorczym dla województw: podkarpackiego, małopolskiego, lubelskiego w latach 2014-2016

\begin{tabular}{|l|c|c|c|c|c|c|c|c|c|}
\hline \multirow{2}{*}{$\begin{array}{l}\text { Wskaźniki } \\
\text { rentowności }\end{array}$} & \multicolumn{3}{|c|}{ Podkarpackie } & \multicolumn{3}{c|}{ Lubelskie } & \multicolumn{3}{c|}{ Malopolskie } \\
\cline { 2 - 10 } & $\mathbf{2 0 1 6}$ & $\mathbf{2 0 1 5}$ & $\mathbf{2 0 1 4}$ & $\mathbf{2 0 1 6}$ & $\mathbf{2 0 1 5}$ & $\mathbf{2 0 1 4}$ & $\mathbf{2 0 1 6}$ & $\mathbf{2 0 1 5}$ & $\mathbf{2 0 1 4}$ \\
\hline $\begin{array}{l}\text { Wskaźnik } \\
\text { płynności I }\end{array}$ & 0,7642 & 0,7198 & 0,9420 & 0,9400 & 0,9706 & 1,5984 & 1,5212 & 1,4519 & 0,6996 \\
\hline $\begin{array}{l}\text { Wskaźnik } \\
\text { płynności II }\end{array}$ & 0,6866 & 0,6440 & 0,8865 & 0,8850 & 0,9160 & 1,4742 & 1,4134 & 1,3389 & 0,6348 \\
\hline $\begin{array}{l}\text { Wskaźnik } \\
\text { płynności III }\end{array}$ & 0,1567 & 0,1836 & 0,1738 & 0,3215 & 0,2994 & 0,2867 & 0,6603 & 0,6368 & 0,6005 \\
\hline
\end{tabular}

Źródło: opracowanie własne na podstawie danych z Biuletynu Centralnego Systemu Informacji w Ochronie Zdrowia

Wskaźnik bieżącej płynności informuje o pokryciu zobowiązań bieżących aktywami obrotowymi. Jego optymalna wartość wynosi od 1,3 do 2,0. Poziom wskaźnika bieżącej płynności finansowej w województwie małopolskim kształtował się w latach 2014-2016 na dobrym poziomie. W dwóch pozostałych województwach był poniżej wartości optymalnej. Oznacza to, że jednostkom w województwie małopolskim wystarczyło środków na pokrycie bieżących zobowiązań.

Wskaźnik szybkiej płynności oznacza pełną możliwość spłaty zobowiązań bieżących z łatwo osiągalnych środków płatniczych. Jego wartość wzorcowa wynosi 1. Należy zwrócić uwagę na bardzo niski poziom wskaźnika w województwie podkarpackim i lubelskim, co wynika z wysokiego stanu zapasów. Może 
to powodować trudności płatnicze i stać się przyczyną powstawania zobowiązań przeterminowanych.

Wskaźnik wypłacalności gotówkowej umożliwia ocenę wypłacalności jednostek gospodarczych $\mathrm{w}$ danym momencie $\mathrm{z}$ wykorzystaniem do tego celu gotówki w kasie, środków na rachunkach bankowych i innych środków pieniężnych. Wzorcowa wartość kształtuje się na poziomie $0,1-0,2$. We wszystkich trzech województwach wskaźnik ten na przestrzeni lat znajdował się na poziomie optymalnym. Wyższy od optymalnego był w województwie małopolskim. Wzrost poziomu wskaźników płynności jest pozytywnym aspektem, wskazującym na wzrost zdolności szpitala do terminowego regulowania bieżących zobowiązań.

Wskaźniki rentowności służą zasadniczo ocenie zdolności do generowania zysków z zaangażowanych przez jednostki kapitałów. Ze względu na fakt, że celem szpitali nie jest maksymalizacja zysku, lecz bilansowanie prowadzonej działalności, wskaźniki rentowności w tym przypadku stosuje się do syntetycznej oceny działalności szpitala. Wskaźniki rentowności województw w badanym okresie zaprezentowano w Tabeli 3.

Tabela 3. Wskaźniki rentowności dla jednostek medycznych w ujęciu zbiorczym dla województw: podkarpackiego, małopolskiego, lubelskiego w latach 2014-2016

\begin{tabular}{|c|c|c|c|c|c|c|c|c|c|}
\hline \multirow{2}{*}{$\begin{array}{c}\text { Nazwa } \\
\text { wskaźnika }\end{array}$} & \multicolumn{3}{|c|}{ Podkarpackie } & \multicolumn{3}{|c|}{ Lubelskie } & \multicolumn{3}{|c|}{ Małopolskie } \\
\hline & 2016 & 2015 & 2014 & 2016 & 2015 & 2014 & 2016 & 2015 & 2014 \\
\hline $\begin{array}{l}\text { Rentowność } \\
\text { majątku }\end{array}$ & $-0,0651$ & $-0,0646$ & $-0,0529$ & $-0,0132$ & $-0,0051$ & $-0,0143$ & 0,0050 & $-0,0045$ & 0,0013 \\
\hline $\begin{array}{l}\text { Rentowność } \\
\text { kapitału } \\
\text { własnego }\end{array}$ & $-0,8641$ & $-0,5314$ & $-0,3063$ & 1,2532 & 1,8535 & $-0,7651$ & 0,0166 & $-0,0152$ & 0,0041 \\
\hline $\begin{array}{l}\text { Rentowność } \\
\text { netto } \\
\text { sprzedaży }\end{array}$ & $-0,0527$ & $-0,0550$ & $-0,0475$ & $-0,0122$ & $-0,0047$ & $-0,0132$ & 0,0045 & $-0,0042$ & 0,0012 \\
\hline $\begin{array}{l}\text { Rentow- } \\
\text { ność brutto } \\
\text { sprzedaży }\end{array}$ & 0,0000 & $-0,0548$ & $-0,0473$ & 0,0000 & $-0,0042$ & $-0,0014$ & 0,0000 & $-0,0038$ & 0,0015 \\
\hline $\begin{array}{l}\text { Rentowność } \\
\text { kapitału } \\
\text { zaangażo- } \\
\text { wanego }\end{array}$ & 0,0000 & $-0,5292$ & $-0,3048$ & $-0,0026$ & 1,6667 & $-0,0841$ & 0,0000 & $-0,0138$ & 0,0052 \\
\hline
\end{tabular}

Źródło: opracowanie własne na podstawie danych z Biuletynu Centralnego Systemu Informacji w Ochronie Zdrowia

Wskaźnik rentowności aktywów (ROA) określa, jaka jest rentowność aktywów przedsiębiorstwa, czyli jaka wielkość zysku przypada na każdą jednostkę pieniężną zaangażowaną w aktywa przedsiębiorstwa. Wskaźnik ten jest uznawany za najlepszy indywidualny wskaźnik kompetencji kierownictwa w zarządzaniu. Im wyższy poziom rentowności aktywów, tym lepsza sytuacja finansowa 
firmy. Wskaźnik ten w analizowanych podmiotach jest na bardzo zróżnicowanym poziomie, występują duże wahania procentowe. Ujemny wskaźnik w województwach podkarpackim, lubelskim i małopolskim może oznaczać generowanie strat.

Wskaźnik rentowności kapitału własnego $(R O E)$ ukazuje rozmiar nadwyżki finansowej osiągniętej z jednej złotówki kapitału własnego, czyli odzwierciedla efektywność kapitałów zaangażowanych przez właścicieli. Im wartość tego wskaźnika jest wyższa, tym korzystniejsza jest sytuacja finansowa podmiotu. Wyższa efektywność kapitału własnego wiąże się z możliwością uzyskania wyższej nadwyżki finansowej. ROE odpowiada na pytanie, jak efektywnie pracuje kapitał własny inwestorów. Wyniki wskaźnika $R O E$ są nie do końca zadowalające, gdyż ich niska wartość może rodzić wątpliwości dotyczące efektywnej gospodarki kapitałów własnych.

Wskaźnik rentowności sprzedaży $(R O S)$ wskazuje, ile zysku netto przypada na jedną złotówkę zrealizowanej sprzedaży. Im wyższa wartość wskaźnika, tym bardziej opłacalna sprzedaż. Wskaźniki w badanych województwach wykazują tendencję spadkową, co nie jest najlepszą sytuacją. Rentowność brutto sprzedaży pokazuje, ile złotych zysku (straty) przed opodatkowaniem wypracowują wszystkie przychody z działalności jednostki gospodarczej, czyli jaki zysk brutto generuje każda złotówka zaangażowana w przychody. W zaprezentowanych w Tabeli 3 danych zaobserwować można spadek rentowności, a we wszystkich województwach w latach 2014-2016 wartości ujemne.

Wskaźnik zwrotu z inwestycji $(R O I)$ określa zdolność kapitałów do generowania zysków, bez względu na to, w jaki sposób zostały one sfinansowane. Wskaźnik rentowności kapitału zaangażowanego w badanych województwach na przestrzeni lat wzrósł, co oznacza wzrost efektywności inwestycji. To z kolei stwarza możliwości dalszego rozwoju. W województwie podkarpackim i lubelskim większość wskaźników rentowności osiągała wartości ujemne, co oznacza trudną sytuację finansową jednostek medycznych w tych regionach.

Wskaźnik pokrycia majątku trwałego kapitałem własnym informuje o stopniu, w jakim kapitał własny pokrywa aktywa trwałe. Im bardziej wskaźnik przekracza 1 , tym wyższa zdolność firmy do spłaty zobowiązań. W żadnym z analizowanych okresów nie została zachowana złota reguła bilansowa, co oznacza, że majątek trwały nie jest w pełni pokryty kapitałem własnym.

Wskaźnik trwałości struktury finansowania pokazuje, jaki jest udział kapitałów długoterminowych w finansowaniu majątku przedsiębiorstwa. Wysokie wartości wskaźnika oznaczają wyższy stopień bezpieczeństwa finansowego. Najniższą wartość wskaźnika osiągnęło województwo podkarpackie.

Kolejnym wskaźnikiem jest wskaźnik pokrycia straty zyskiem bieżącym (im wyższa wartość, tym lepiej). Wartość optymalna od 0 do 1 oznacza, że zysk wygenerowany w danym okresie nie wystarczy do całkowitego pokrycia strat. 
Wskaźnik wyższy od jedności oznacza, że istnieje możliwość pokrycia wielkości strat z okresów ubiegłych zyskiem z bieżącego okresu, natomiast wartość wskaźnika niższa od jedności wskazuje na niemożność pokrycia strat. Wartości wskaźników zaprezentowanych w Tabeli 4 wynoszą poniżej jedności w województwie małopolskim, co oznacza możliwość wystąpienia problemów z pokryciem ewentualnych strat. Wskaźniki powyżej jedności odnotowały w 2016 roku województwa podkarpackie i lubelskie.

Tabela 4. Wskaźniki struktury majątku dla jednostek medycznych w ujęciu zbiorczym dla województw: podkarpackiego, małopolskiego, lubelskiego w latach 2014-2016

\begin{tabular}{|c|c|c|c|c|c|c|c|c|c|}
\hline \multirow{2}{*}{ Nazwa wskaźnika } & \multicolumn{3}{|c|}{ Podkarpackie } & \multicolumn{3}{|c|}{ Lubelskie } & \multicolumn{3}{|c|}{ Małopolskie } \\
\hline & 2016 & 2015 & 2014 & 2016 & 2015 & 2014 & 2016 & 2015 & 2014 \\
\hline $\begin{array}{l}\text { Wskaźnik } \\
\text { pokrycia majątku } \\
\text { trwałego kapitałem } \\
\text { własnym }\end{array}$ & 0,0996 & 0,1557 & 0,2177 & $-0,0147$ & $-0,0038$ & 0,0261 & 0,4107 & 0,3931 & 0,4190 \\
\hline $\begin{array}{l}\text { Trwałość struktury } \\
\text { finansowania }\end{array}$ & 0,1834 & 0,2404 & 0,2391 & 0,2107 & 0,2126 & 0,2290 & 0,3555 & 0,3581 & 0,3606 \\
\hline $\begin{array}{l}\text { Wskaźnik } \\
\text { pokrycia straty } \\
\text { zyskiem bieżącym }\end{array}$ & 1,0144 & 1,2209 & 2,5532 & 2,7214 & 0,3723 & $-15,896$ & $-1,1626$ & $-3,5737$ & 0,1621 \\
\hline $\begin{array}{l}\text { Wskaźnik relacji } \\
\text { straty do kapitałów } \\
\text { własnych }\end{array}$ & $-0,8641$ & $-0,5314$ & $-0,3063$ & 1,2532 & 1,8535 & $-0,7651$ & 0,0166 & $-0,0152$ & 0,0041 \\
\hline
\end{tabular}

Źródło: opracowanie własne na podstawie danych z Biuletynu Centralnego Systemu Informacji w Ochronie Zdrowia

Wskaźnik relacji straty do kapitałów własnych jest pozytywnie oceniany, gdy jego wartość wynosi mniej niż 1. Dostarcza on informacji o dostatecznej ilości środków do pokrycia straty i - w odwrotnej sytuacji - o braku możliwości pokrycia. Wartości tego wskaźnika w badanym okresie nie przekroczyły jedności, co można interpretować jako pozytywny symptom posiadania środków na pokrycie strat. W 2016 roku w województwie lubelskim wskaźnik ten miał wartość powyżej 1, co można interpretować jako brak możliwości pokrycia strat z własnych środków finansowych.

Analiza zadłużenia placówki medycznej pozwala ustalić, czy wielkość zaangażowanych kapitałów obcych nie zagraża bezpieczeństwu placówki z punktu widzenia zdolności obsługi zadłużenia.

Analizę wskaźnikową zadłużenia szpitala można przeprowadzić na podstawie:

1) wskaźnika ogólnego zadłużenia,

2) wskaźnika udziału zadłużenia w kapitale własnym,

3) wskaźnika udziału kapitału własnego w finansowaniu aktywów,

4) wskaźnika zadłużenia długoterminowego, 
5) wskaźnika trwałości struktury finansowania,

6) wskaźnika pokrycia majątku trwałego kapitałem stałym.

Tabela 5. Wskaźnik zadłużenia dla jednostek medycznych w ujęciu zbiorczym dla województw: podkarpackiego, małopolskiego, lubelskiego w latach 2014-2016

\begin{tabular}{|l|c|c|c|c|c|c|c|c|c|}
\hline \multicolumn{1}{|c|}{$\begin{array}{c}\text { Nazwa } \\
\text { wskaźnika }\end{array}$} & \multicolumn{3}{|c|}{ Podkarpackie } & \multicolumn{3}{c|}{ Lubelskie } & \multicolumn{3}{c|}{ Malopolskie } \\
\cline { 2 - 10 } & $\mathbf{2 0 1 6}$ & $\mathbf{2 0 1 5}$ & $\mathbf{2 0 1 4}$ & $\mathbf{2 0 1 6}$ & $\mathbf{2 0 1 5}$ & $\mathbf{2 0 1 4}$ & $\mathbf{2 0 1 6}$ & $\mathbf{2 0 1 5}$ & $\mathbf{2 0 1 4}$ \\
\hline $\begin{array}{l}\text { Wskaźnik } \\
\text { zadłużenia } \\
\text { ogółem }\end{array}$ & 0,4567 & 0,4048 & 0,3533 & 0,5222 & 0,5049 & 0,5035 & 0,2169 & 0,2242 & 0,2131 \\
\hline $\begin{array}{l}\text { Wskaźnik } \\
\text { długoter- } \\
\text { minowego } \\
\text { zadłużenia }\end{array}$ & 0,1081 & 0,1188 & 0,0664 & 0,2212 & 0,2153 & 0,2104 & 0,0526 & 0,0620 & 0,0443 \\
\hline $\begin{array}{l}\text { Wskaźnik } \\
\text { struktury } \\
\text { zobowią- } \\
\text { zań }\end{array}$ & 0,2367 & 0,2934 & 0,1879 & 0,4237 & 0,4265 & 0,4178 & 0,2426 & 0,2765 & 0,2080 \\
\hline $\begin{array}{l}\text { Wskaźnik } \\
\text { zadłużenia } \\
\text { kapitałów } \\
\text { własnych }\end{array}$ & 6,0648 & 3,3281 & 2,0456 & $-49,604$ & $-184,29$ & 27,000 & 0,7162 & 0,7569 & 0,6736 \\
\hline $\begin{array}{l}\text { Wskaźnik } \\
\text { dług. za- } \\
\text { dłużenia } \\
\text { kapitałów } \\
\text { własnych }\end{array}$ & 1,4356 & 0,9764 & 0,3843 & $-21,016$ & $-78,592$ & 11,282 & 0,1738 & 0,2093 & 0,1401 \\
\hline
\end{tabular}

Źródło: opracowanie własne na podstawie danych z Biuletynu Centralnego Systemu Informacji w Ochronie Zdrowia

Dane dotyczące zadłużenia szpitali przedstawia Tabela 5. Wskaźnik zadłużenia ogółem wyraża udział kapitałów obcych w finansowaniu aktywów firmy. Jest bardzo istotny z punktu widzenia pożyczkodawców, którzy w razie upadłości przedsiębiorstwa odzyskują swoje należności z majątku firmy. Dopuszczalna wartość wskaźnika powinna mieścić się w przedziale 0,57-0,67. Wartość poniżej 0,57 może być interpretowana jako nieracjonalne zarządzanie źródłami finansowania, natomiast wskaźnik na poziomie wyższym niż 0,67 świadczy o wysokim ryzyku utraty przez jednostkę gospodarczą zdolności do spłaty długów. W analizowanych województwach wskaźniki w latach 2014-2016 były poniżej poziomu dopuszczalnego.

Jeżeli zobowiązania długoterminowe dominują w ogólnym zadłużeniu, należy stwierdzić, że sytuacja finansowa jest lepsza od tej, w której przeważają zobowiązania krótkoterminowe. Określają one stopień zadłużenia i tym samym oceniają jego wypłacalność w długim okresie. Korzystna sytuacja występuje, gdy wskaź- 
nik jest większy od 0,5. Jego wartości w analizowanych województwach znacznie odbiegały od wartości granicznej, czyli 0,5 , co może rodzić wątpliwości dotyczące wypłacalności jednostek.

Wskaźnik zadłużenia kapitałów własnych informuje o poziomie zadłużenia kapitałów własnych przedsiębiorstwa i zarazem relacji kapitałów obcych do kapitałów własnych jako źródeł finansowania przedsiębiorstwa. Przyjmuje się, że wielkość tego wskaźnika nie powinna być wyższa niż 1 dla przedsiębiorstw dużych i średnich oraz 3 dla przedsiębiorstw małych. Banki zazwyczaj niechętnie udzielają kredytu inwestycyjnego, gdy kapitał własny w stosunku do zamierzonego kredytu nie osiąga relacji 1: 1. Wzrost wartości tego wskaźnika w województwie podkarpackim może oznaczać coraz większe zaangażowanie obcych źródeł finansowania w stosunku do źródeł własnych, co w dłuższej perspektywie może być zjawiskiem niekorzystnym.

Wskaźnik długoterminowego zadłużenia kapitałów własnych, zwany też wskaźnikiem długu, wskaźnikiem ryzyka lub wskaźnikiem dźwigni, informuje o poziomie pokrycia zobowiązań długoterminowych kapitałem własnym. Zgodnie z normą dla tego wskaźnika najbardziej pożądana jest wartość 0,5 , natomiast jego racjonalna wysokość powinna zawierać się w przedziale $0,5-1$. W przypadku przekroczenia przez ten wskaźnik poziomu 1 przedsiębiorstwo uważa się za silnie zadłużone. W analizowanych województwach wskaźnik osiągał wartości poniżej 0,5 (a więc poziom bezpieczny), co oznacza bardzo małe zaangażowanie zobowiązań długoterminowych (powyżej roku).

Ocenę efektywności wykorzystania zasobów majątkowych szpitali wspomagają wskaźniki sprawności działania. W tabeli 6 zaprezentowano wskaźniki sprawności działania w analizowanych województwach w latach 2014-2016. Wzrost wskaźnika rotacji aktywów oraz spadek wskaźnika zaangażowania aktywów może świadczyć o wyższej efektywności wykorzystania zasobów szpitali w badanych latach.

Wskaźnik rotacji należności informuje o tym, ile razy jednostka odtwarza swoje należności w ciągu roku. Przyjmuje się, że wartość wskaźnika rotacji należności powinna wynosić od 7 do 17 razy. Wówczas wartość wskaźnika cyklu inkasa należności w dniach wynosi od 52 do 21. Jeżeli okres ten jest dłuższy i przekracza zwyczajowo przyjęty termin kredytu handlowego, to jednostka gospodarcza może być narażona na kłopoty finansowe. W rozpatrywanych województwach tylko lubelskie przekroczyło tę wartość, co może świadczyć o zatorach płatniczych.

Wskaźnik szybkości spłaty zobowiązań w dniach informuje, jaki jest średni czas regulowania zobowiązań w przedsiębiorstwie. Na ogół pozytywnie ocenia się wydłużone terminy spłaty zobowiązań. Jednak długi termin spłaty jest negatywnie odbierany przez kontrahentów. $Z$ punktu widzenia płynności finansowej pożądane jest, aby wskaźnik kształtował się na niższym poziomie od wskaźnika cyklu inkasa należności. W omawianym przypadku wskaźnik szybkości spłaty zobowiązań w dniach nie jest pozytywnie oceniany, ponieważ jest bardzo wysoki w stosunku do wskaźnika rotacji należności we wszystkich województwach. 


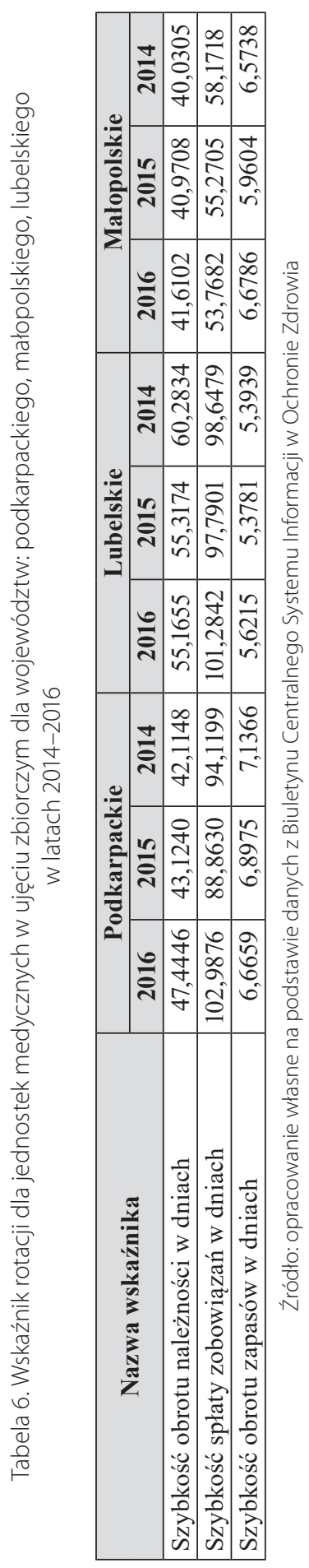


Wskaźnik rotacji zapasów określa, ile razy w ciągu rozpatrywanego okresu nastąpił obrót zapasami. Wskaźnik cyklu obrotu w dniach informuje natomiast o długości trwania jednego cyklu obrotu. Im liczba obrotów jest wyższa, tym krótszy jest cykl obrotu zapasami w dniach i na ogół lepsza gospodarka zapasami. W analizowanych jednostkach medycznych wskaźnik rotacji zapasów był niski i nie przekraczał 7 dni, co sugeruje, iż gospodarowanie zapasami raczej nie przysparzało analizowanym jednostkom problemu.

\section{Analiza dyskryminacyjna}

Modele dyskryminacyjne, określane także jako funkcja Z-score, sprowadzają ocenę kondycji przedsiębiorstwa do analizy pojedynczego wskaźnika. Wskaźnik Z-score to ogólna nazwa formuły łączącej różne wskaźniki finansowe z uwzględnieniem systemu ważonego (Antonowicz, 2007: 27-28). Podobnie jak w tradycyjnej analizie wskaźnikowej w modelu dyskryminacyjnym wykorzystuje się dane zawarte w sprawozdaniach finansowych. Metoda ta jest jednak pozbawiona zasadniczej wady analizy wskaźnikowej, jaką jest trudność w jednoznacznej ocenie sytuacji finansowej przedsiębiorstwa. Wykorzystanie wielu wskaźników często zaciemnia obraz sytuacji przedsiębiorstwa, co powoduje konieczność ich selekcji. $\mathrm{Z}$ drugiej strony selekcja taka grozi subiektywizmem. Rozwiązaniem tego problemu są właśnie modele dyskryminacyjne, które - sprowadzając ocenę sytuacji finansowej do jednej wartości liczbowej - wykluczają sprzeczności interpretacyjne. Biorąc pod uwagę liczbę wykorzystywanych zmiennych, modele dyskryminacyjne dzieli się na (Rogowski, 1999):

1) modele jednowymiarowe - opracowane w początkowym okresie rozwoju prognozowania upadłości przedsiębiorstwa; kondycję przedsiębiorstwa charakteryzuje w nich zbiór pojedynczych równań opisujących oddzielnie wybrane wskaźniki ekonomiczne;

2) modele wielowymiarowe - oparte na jednoczesnej analizie wielu wskaźników finansowych.

Ze względu na zdolności do prognozowania sytuacji finansowej przedsiębiorstwa szersze zastosowanie mają modele wielowymiarowe. Dzięki agregacji różnych wskaźników finansowych i przypisaniu im wag wyrażających rolę danej zmiennej w syntetycznej wielkości wynikowej umożliwiają one podział przedsiębiorstw na podmioty znajdujące się w dobrej i złej sytuacji finansowej. Do najpopularniejszych modeli zagranicznych autorów należą między innymi modele: E. Altmana, R. Edminstera, E. Deakina, G. Springate'a, R. Tafflera, H. Hiehausa, K. Beermana (Nowak, 1998: 237-247; Siemińska, 2002: 208-220; Waśniewski, Skoczylas, 2002: 471-476; Hamrol, Czajka, Piechocki, 2004a: 34-38). 
Do popularnych modeli opracowanych przez polskich naukowców należą: model J. Gajdki i D. Stosa, model E. Mączyńskiej oraz model poznański. Zaletą tych modeli jest wysoki procent trafności prognoz budowanych na ich podstawie.

Model J. Gajdki i D. Stosa stanowi jedną z pierwszych znaczących aplikacji metody dyskryminacyjnej w polskich realiach gospodarczych. Trafność prognoz opartych na tym modelu wynosi 93\% (Gajdka, Stos, 1996: 59-63). Wśród wskaźników wykorzystywanych w modelu dominuje wskaźnik rentowności majątku, określający efektywność wykorzystania zaangażowanych zasobów majątkowych. Istotną rolę ogrywają także wskaźniki rentowności sprzedaży oraz udziału kapitałów obcych w finansowaniu majątku przedsiębiorstwa. Mniejsze znaczenie przypisuje się natomiast wskaźnikowi efektywności zaangażowanych zasobów majątkowych oraz udziału zobowiązań bieżących w kosztach uzyskania przychodu. Model zaproponowany przez E. Mączyńską powstał na podstawie wyników analizy kilku tysięcy przedsiębiorstw (Mączyńska, 1994: 44). Sprawność prognozowania upadłości przedsiębiorstw na podstawie tego modelu wyniosła 94,11 (Mączyńska, 1994: 44; Antonowicz, 2007: 55). W grupie wskaźników wykorzystywanych w konstrukcji modelu dominują wskaźniki efektywności wykorzystania majątku oraz rentowności przychodów ze sprzedaży. Duże znaczenie przypisuje się też ocenie zdolności kredytowej, a więc możliwości regulowania zobowiązań z wygospodarowanej nadwyżki pieniężnej. Mniejszą rolę odgrywają: wskaźnik zaangażowania zapasów, produktywności (obrotowości) majątku oraz stopnia zadłużenia. Model poznański to jedna z najnowszych propozycji oceny sytuacji finansowej przedsiębiorstw w Polsce. Został on opracowany przez M. Hamrola, B. Czajkę i M. Piechockiego na podstawie badania sprawozdań finansowych stu polskich spółek prawa handlowego. Budowa modelu oparta jest na wielkości stałej oraz czterech wskaźnikach finansowych. Jego skuteczność została określona na poziomie 92,98\% (Rolbecki, 2000: 22; Hamrol, Czajka, Piechocki, 2004b: 35-39). Wśród wskaźników wykorzystywanych w konstrukcji modelu poznańskiego dominuje wskaźnik rentowności sprzedaży.

Duże znaczenie przypisuje się także wskaźnikowi udziału kapitału stałego w finansowaniu majątku przedsiębiorstwa. Informuje on o stabilności finansowej podmiotu. Mniejszą rolę odgrywają: wskaźnik rentowności majątku oraz wskaźnik płynności finansowej, informujący o możliwości regulowania zobowiązań bieżących (Bombiak, 2010: 142-156). W konstrukcji omawianych modeli (zob. Tabela 7) zastosowano zatem wskaźniki o charakterze uniwersalnym, to jest takie, które są powszechnie wykorzystywane $\mathrm{w}$ analizie finansowej.

W 2001 roku A. Hołda poddał analizie próbę czterdziestu przedsiębiorstw upadłych oraz czterdziestu, które charakteryzowała dobra sytuacja finansowa (Hołda, 2001). Stanowiły one homogeniczną grupę zebraną w Europejskiej Klasyfikacji Działalności Gospodarczej. Dane pochodziły z lat 1993-1996. Analiza obejmowała trzy etapy. W pierwszym wybrano dwadzieścia osiem wskaźników 
finansowych z grup płynności, rentowności, obrotowości oraz stopnia zadłużenia. Dla przedsiębiorstw upadłych wskaźniki te zostały wyznaczone na rok przed ogłoszeniem bankructwa. W drugim etapie wyodrębniono ze wstępnego zestawu trzynaście, a w trzecim pięć zmiennych objaśniających. Również D. Wędzki przedstawił wiele modeli logitowych upadłości w polskiej gospodarce. Prezentowany model logitowy jest jednym z konstrukcji prognozy bankructwa za pomocą modeli regresji logistycznej. Modele logitowe posiadają zalety do modeli dyskryminacyjnych (Wojnar, 2014: 219-220). Opierają się na słabych założeniach, gdyż nie jest wymagalna normalność rozkładu poszczególnych zmiennych objaśniających, a wskaźniki finansowe z reguły mają rozkład asymetryczny, nie wymagają też założenia o równości macierzy wariancji w grupie bankrutów i firm dobrze działających na rynku. Modele logitowe są zatem użytecznym narzędziem do prognozowania bankructwa (Pociecha, Pawełek, Baryła, Augustyn, 2014: 27).

Tabela 7. Konstrukcja wybranych modeli dyskryminacyjnych

\begin{tabular}{|c|c|}
\hline Nazwa & Postać liniowa funkcji \\
\hline $\begin{array}{l}\text { Model } \\
\text { Mączyńskiej }\end{array}$ & $\begin{array}{l}\qquad Z M=1,5 \cdot x_{1}+0,08 \cdot x_{2}+10 \cdot x_{3}+5 \cdot x_{4}+0,3 \cdot x_{5}+0,1 \cdot x_{6} \\
x_{1}-\text { pokrycie długu zyskiem i amortyzacją }=\text { wynik brutto }+ \text { amortyzacja/zobo- } \\
\quad \text { wiązania ogółem } \\
x_{2}-1 \text { stopa zadłużenia }=\text { suma bilansowa/zobowiązania ogółem } \\
x_{3}-\text { rentowność majątku }=\text { wynik brutto/suma bilansowa } \\
x_{4}-\text { rentowność obrotu }=\text { wynik brutto/przychody ze sprzedaży } \\
x_{5}-1 / \text { rotacja zapasów }=\text { wartość zapasów/przychody ze sprzedaży } \\
x_{6}-\text { rotacja aktywów }=\text { przychody ze sprzedaży/suma bilansowa }\end{array}$ \\
\hline $\begin{array}{l}\text { Model } \\
\text { Hołdy }\end{array}$ & $\begin{array}{l}Z H=0,605+\left(6,81 \cdot 10^{-1}\right) \cdot P W P-\left(1,96 \cdot 10^{-2}\right) \cdot S Z+\left(9,69 \cdot 10^{-3}\right) \cdot Z M+(6,72 \cdot \\
\left.10^{-4}\right) \cdot W O Z+\left(1,5 \cdot 10^{-1}\right) \cdot R M\end{array}$ \\
\hline $\begin{array}{l}\text { Model } \\
\text { poznański }\end{array}$ & $\begin{array}{l}\quad F D=3,562 \cdot W_{7}+1,588 \cdot W_{16}+4,288 \cdot W_{5}+6,719 \cdot W_{13}-2,368 \\
W_{7}-\text { wynik finansowy netto/majątek całkowity } \\
W_{16}-\text { majątek obrotowy }- \text { zapasy/zobowiązania krótkoterminowe } \\
W_{5}-\text { kapitał stały/majątek całkowity } \\
W_{13}-\text { wynik finansowy ze sprzedaży/przychody ze sprzedaży }\end{array}$ \\
\hline
\end{tabular}




\begin{tabular}{|c|c|}
\hline Nazwa & Postać liniowa funkcji \\
\hline $\begin{array}{l}\text { Model } \\
\text { Gajdki } \\
\text { i Stosa }\end{array}$ & $\begin{array}{l}Z(x)=0,7732059-0,0856425 \cdot x_{1}+0.0007747 \cdot x_{2}+0,9220985 \cdot x_{3}+0,6535995 \cdot \\
x_{4}-0,594687 \cdot x_{5} \\
x_{1}-\text { rotacja aktywów = przychody netto ze sprzedaży/średnia wartość akty- } \\
\quad \text { wów w roku } \\
x_{2}-\text { rotacja zobowiązań w dniach krótkoterminowych = średnia wartość zobo- } \\
\quad \text { wiązań/koszt wytworzenia produkcji sprzedanej } \\
x_{3}-\text { rentowność aktywów }=\text { zysk netto/średnia wartość aktywów w roku } \\
x_{4}-\text { marża zysku brutto ze sprzedaży = zysk brutto/przychody netto ze sprzedaży } \\
x_{5}-\text { stopa zadłużenia = zobowiązania ogółem/aktywa ogółem }\end{array}$ \\
\hline $\begin{array}{l}\text { Model } \\
\text { Hadasika }\end{array}$ & $\begin{array}{l}\quad Z=2,36261+0,365425 \cdot x_{1}-0,765526 \cdot x_{2}-2,40435 \cdot x_{3}+1,59079 \cdot \\
\qquad x_{4}+0,00230258 \cdot x_{5}-0,0127826 \cdot x_{6} \\
x_{1}-\text { aktywa obrotowe/zobowiązania krótkoterminowe } \\
x_{2}-\text { aktywa obrotowe }- \text { zapasy/zobowiązania krótkoterminowe } \\
x_{3}-\text { zobowiązania ogółem/suma bilansowa } \\
x_{4}-\text { kapitał pracujący/zobowiązania ogółem } \\
x_{5}-\text { należności } \cdot 365 / \text { przychody ze sprzedaży } \\
x_{6}-\text { zapasy } \cdot 365 / \text { przychody ze sprzedaży } \\
\text { W tym modelu, na podstawie wartości funkcji } Z \text {, przedsiębiorstwa dzieli się na: } \\
\text { a) zagrożone upadłością, gdy } Z \text { wynosi }-1,71759 \text { lub mniej, } \\
\text { b) znajdujące się w tzw. szarej strefie, gdy } Z \text { mieści się w przedziale od -1,71759 } \\
\text { do } 0,9689 \text {, } \\
\text { c) nieposiadające trudności finansowych, gdy } Z \text { wynosi co najmniej } 0,9689 .\end{array}$ \\
\hline $\begin{array}{l}\text { Model } \\
\text { Wędzkiego }\end{array}$ & $\begin{array}{l}\qquad Z W=-x_{1}-0,256 \cdot x_{2}-0,044 \cdot x_{3}-4,373 \cdot x_{4}+1 \\
x_{1}-\text { aktywa obrotowe }+\mathrm{RMKCZ} / \text { zobowiązania krótkoterminowe }+ \text { RMKB } \\
x_{2}-\text { odsetki do zapłacenia/wynik na działalności gospodarczej }+ \text { odsetki } \\
x_{3}-\text { przychody ze sprzedaży }+ \text { pozostałe przychody operacyjne }+ \text { przychody } \\
\quad \text { finansowe/suma bilansowa } \\
x_{4}-\text { wynik brutto/przychody ze sprzedaży }+ \text { pozostałe przychody operacyj- } \\
\quad \text { ne }+ \text { przychody finansowe } \\
\text { Wartością graniczną tutaj jest } 0,5 \text {. } \\
Z>0,5 \text { - firma upadnie, } Z<0,5-\text { firma przetrwa. }\end{array}$ \\
\hline
\end{tabular}

Źródło: Mączyńska, 1994: 38; Borowiecki, 1996: 59-63; Hamrol, Czajka, Piechocki, 2004b: 35-39; Hołda, 2006: 56-58; Pociecha, Pawełek, Baryła, Augustyn, 2014: 27

Tabela 8. Analiza dyskryminacyjna badanych województw

\begin{tabular}{|l|c|c|c|c|c|c|c|c|c|}
\hline \multirow{2}{*}{$\begin{array}{c}\text { Modele } \\
\text { dyskryminacyjne }\end{array}$} & \multicolumn{3}{c|}{ Podkarpackie } & \multicolumn{3}{c|}{ Lubelskie } & \multicolumn{3}{c|}{ Malopolskie } \\
\cline { 2 - 11 } & $\mathbf{2 0 1 6}$ & $\mathbf{2 0 1 5}$ & $\mathbf{2 0 1 4}$ & $\mathbf{2 0 1 6}$ & $\mathbf{2 0 1 5}$ & $\mathbf{2 0 1 4}$ & $\mathbf{2 0 1 6}$ & $\mathbf{2 0 1 5}$ & $\mathbf{2 0 1 4}$ \\
\hline Model Mączyńskiej & $\mathrm{N}$ & Z & Z & N & N & N & N & N & N \\
\hline Model Hołdy & N & N & N & N & N & N & N & N & N \\
\hline Model poznański & N & N & N & N & N & N & N & N & N \\
\hline Model Gajdki i Stosa & N & N & N & N & N & N & N & N & N \\
\hline Model Hadasika & S & N & N & S & S & S & N & N & N \\
\hline Model Wędzkiego & N & N & N & N & N & N & N & N & N \\
\hline
\end{tabular}

$\mathrm{N}$ - niezagrożone upadłością, Z - zagrożone upadłością, S - szara strefa. 
Weryfikacja przedstawionych modeli (Tabela 8) pozwala stwierdzić, że - badając jednostki medyczne w trzech wybranych województwach - wszystkie modele (poznański, E. Mączyńskiej, Hołdy, Gajdki i Stosa, Hadasika, Wędzkiego) trafnie sklasyfikowały badany obszar. Za pomocą tych funkcji każdej ze spółek przypisano rzeczywisty stan funkcjonowania. Modelem, z którego wykorzystaniem poprawnie oceniono kondycję finansową i zauważono możliwość upadłościowe, był model E. Mączyńskiej, natomiast model Hadasika wskazał na występujące trudności finansowe w dwóch województwach: w latach 2015-2016 w województwie małopolskim i roku 2016 w województwie podkarpackim.

\section{Zakończenie}

Ciągły proces zmian i reform w systemie ochrony zdrowia wpływa na zapotrzebowanie i wzrost roli informacji finansowych, niezbędnych do zarządzania finansami oraz majątkiem placówki medycznej. Jednym z najważniejszych narzędzi, umożliwiającym ocenę kondycji finansowej oraz ułatwiającym podejmowanie trafnych decyzji, jest analiza finansowa. Jest to metoda badań analitycznych polegająca na obliczaniu wskaźników na podstawie danych zawartych w sprawozdaniach finansowych i na ich ocenie porównawczej w czasie i przestrzeni. W Polsce brakuje instytucji odpowiedzialnej za cykliczne tworzenie systemu informacji finansowej na potrzeby zarządzania jednostkami ochrony zdrowia. Natomiast w placówkach medycznych stosowanie narzędzi analizy finansowej, umożliwiających ocenę sytuacji finansowej każdego szpitala, leży w gestii zarządzających tymi placówkami i nie jest powszechnie stosowane. Każdy podmiot wykorzystujący informacje związane z kondycją finansową kształtuje ich różny zakres przez dobór odpowiednich miar i wskaźników cechujących określone obszary działalności oraz wyniki. W ocenie placówki medycznej pomocny jest zestaw miar i wskaźników analitycznych, dostarczanych przez analizę wskaźnikową. Zarządzanie finansami czy wykorzystanie analizy wskaźnikowej w zarządzaniu placówką medyczną to niezbędny warunek osiągnięcia wyznaczonego celu. Optymalizacja zasobów finansowych jednostek gospodarczych przy jednoczesnym uwzględnieniu zadowolenia pacjenta determinowana jest w praktyce koniecznością zastosowania instrumentów zarządzania finansami. Zarządzanie finansami placówki służby zdrowia jest zdecydowanie trudniejszym zadaniem od zarządzania środkami pieniężnymi podmiotów z innych branż. Może to oznaczać, że placówki lecznictwa zamkniętego zmuszone są szukać narzędzi pozwalających na skuteczne oraz efektywne zarządzanie oparte na konkretnych danych, a nie na intuicyjnie określanych oczekiwaniach menedżerów. Oceniając jednak wykorzystanie mierników kondycji finansowej szpitala w praktyce, należy zauważyć, że w obranej strategii działalności 
jednostki medycznej analiza finansowa powinna być stosowana w takim zakresie, w jakim może być w tej dziedzinie użyteczna.

Weryfikacja trafności klasyfikacji za pomocą wybranych modeli wielowymiarowej analizy dyskryminacyjnej wykazała, że modele te mają wysoką jakość predykcji. Trzeba jednak podkreślić, że badania były przeprowadzane na określonej próbie badawczej i każda zmiana w ramach grupy badanych może skutkować zmianą poziomu trafności predykcji. Warto wspomnieć, że omawiane modele mogą być wykorzystane nie tylko do predykcji bankructwa. Umożliwiają również zbadanie ogólnej kondycji jednostek publicznych w Polsce w szybki i prosty sposób, bez ponoszenia wysokich kosztów. Mogą służyć jako system wczesnego ostrzegania przed wystąpieniem stanu zagrożenia upadkiem. Zmiany otoczenia gospodarczego wpływają na bieżącą kondycję finansową i zdolność do kontynuowania działalności. Trafność prognoz bankructwa w znacznym stopniu zależy od szybko zmieniającego się otoczenia zewnętrznego. Wnioskiem z powyższych rozważań może być stwierdzenie, że w procesie prognozowania bankructwa nie należy opierać się tylko na wskaźnikach finansowych z przeszłości - trzeba je modyfikować zmiennymi czasowymi wskazującymi na stan koniunktury.

\section{Bibliografia}

Antonowicz P. (2007), Metody oceny i prognozowania kondycji ekonomiczno-finansowej przedsiębiorstw, Ośrodek Doradztwa i Doskonalenia Kadr, Gdańsk.

Bień W. (2005), Zarządzanie finansami przedsiębiorstwa, Wydawnictwo Difin, Warszawa.

Biuletyn Centralnego Systemu Informacji w Ochronie Zdrowia, https://www.csioz.gov.pl [dostęp: 28.12.2017].

Bombiak E. (2010), Modele dyskryminacyjne jako metoda oceny sytuacji finansowej przedsiębiorstwa, „Zeszyty Naukowe Akademii Podlaskiej w Siedlcach”, nr 86, s. 141-152.

Borowiecki R. (red.) (1996), Restrukturyzacja w procesie przeksztatceń i rozwoju przedsiębiorstw, Akademia Ekonomiczna, Kraków.

Gajdka J., Stos D. (1996), Wykorzystanie analizy dyskryminacyjnej w ocenie kondycji finansowej przedsiębiorstw, [w:] R. Borowiecki (red.), Restrukturyzacja w procesie przeksztatceń i rozwoju przedsiębiorstw, Akademia Ekonomiczna, Kraków.

Golimowska S. (red.) (2008), Raport: Finansowanie ochrony zdrowia w Polsce, Zielona Księga II, Warszawa.

Hamrol M., Czajka B., Piechocki M. (2004a), Analiza dyskryminacyjna. Przegląd najważniejszych modeli, „Przegląd Organizacji”, nr 4, s. 34-38.

Hamrol M., Czajka B., Piechocki M. (2004b), Upadłość przedsiębiorstwa-model analizy dyskryminacyjnej, „Przegląd Organizacji”, nr 6, s. 35-39.

Hass-Symotiuk M. (red.) (2008), Rachunkowość i sprawozdawczość finansowa zakładów opieki zdrowotnej, Ośrodek Doradztwa i Doskonalenia Kadr, Gdańsk.

Hołda A. (2001), Prognozowanie bankructwa jednostki w warunkach gospodarki polskiej z wykorzystaniem funkcji dyskryminacyjnej, „Rachunkowość”, nr 5, s. 306-310.

Hołda A. (2006), Zasada kontynuacji działalności i prognozowanie upadłości w polskich realiach gospodarczych, Wydawnictwo Akademii Ekonomicznej, Kraków. 
Hrynkiewicz J. (red.) (2001), Mierniki i wskaźniki w systemie ochrony zdrowia, Instytut Spraw Publicznych, Warszawa.

Mączyńska E. (b.r.w.), Systemy wczesnego ostrzegania, http://www.pte.pl/pliki/2/11/E.\%20Maczynska\%20-tezy\%20na\%209.03.09.pdf [dostęp: 28.06.2007].

Mączyńska E. (1994), Ocena kondycji przedsiębiorstwa (uproszczone metody), „Życie Gospodarcze", nr 38, s. 42-45.

Nowak E. (2005), Analiza sprawozdań finansowych, Polskie Wydawnictwo Ekonomiczne, Warszawa.

Nowak M. (1998), Praktyczna ocena kondycji finansowej przedsiębiorstwa. Metody i ograniczenia, Fundacja Rozwoju Rachunkowości, Warszawa.

Pociecha J., Pawełek B., Baryła M., Augustyn S. (2014), Statystyczne metody prognozowania bankructwa w zmieniajacej się koniunkturze gospodarczej, Fundacja Uniwersytetu Ekonomicznego w Krakowie, Kraków.

Resort zdrowia, Zadlużenie ZOZ-ów jest najniższe od 2002 r., http://www2.mz.gov.pl/wwwfiles/ ma_struktura/docs/raport_zk_211204.pdf [dostęp: 2.01.2018].

Rogowski W.K. (1999), Możliwości wczesnego rozpoznawania symptomów zagrożenia zdolności płatniczej przedsiębiorstwa, „Bank i Kredyt”, nr 6, s. 56-72.

Rolbecki R. (2000), Analiza dyskryminacji w ocenie sytuacji finansowej przedsiębiorstw, „Ekonomika i Organizacja Przedsiębiorstwa", nr 9, s. 22-24.

Siemińska E. (2002), Metody pomiaru i oceny kondycji finansowej przedsiębiorstwa, Wydawnictwo Dom Organizatora, Torun.

Sierpińska M., Jachna T. (1997), Ocena przedsiębiorstwa wedtug standardów światowych, Wydawnictwo Naukowe PWN, Warszawa.

Tuczapski K. (2009), Samorzady powinny przekształcać publiczne zakłady opieki zdrowotnej w spótki, „Gazeta Prawna”, 17.02, nr 33, http://www.szpital.com.pl/dane/2009/aktualnosci/20090218prasa.pdf [dostęp: 17.02.2009].

Waśniewski T., Skoczylas W. (2002), Teoria i praktyka analizy finansowej w przedsiębiorstwie, Fundacja Rozwoju Rachunkowości, Warszawa.

Wojnar J., Ocena skuteczności modeli analizy dyskryminacyjnej do prognozowania zagrożenia finansowego spótek giełdowych, ,Zeszyty Naukowe Małopolskiej Wyższej Szkoły Ekonomicznej w Tarnowie", nr 1(24), s. 219-231.

Wrzosek S. (2006), Zarzadzanie finansami przedsiębiorstw, Wydawnictwo Akademii Ekonomicznej, Wrocław. 


\title{
Utility of the Assessment Measures of the Financial Condition in Hospitality on a Sample of Selected Voivodships
}

\begin{abstract}
The business activity of medical units is assessed on the basis of economic resources that could allow to assess the effectiveness of the examined business entity. The set of analytical measures and indicators is helpful in assessing the financial condition of the medical institution. The article aims to assess the utility of measures of the financial position of medical units in three selected voivodships: podkarpackie, małopolskie and lubelskie in 2014-2016. In order to achieve the goal, sources necessary for the analysis of the institutions' indicators were used. The work contains an overview of popular Polish models of discriminant analysis in the field of forecasting the bankruptcy of medical units. Changes in the business environment affect the current financial condition and the ability to continue operations. The accuracy of bankruptcy forecasts depends to a large extent on the rapidly changing external environment. The conclusion from the above considerations may be the statement that in the process of forecasting bankruptcy, one can not rely only on financial indicators from the past, and they can be modified with time variables indicating the condition of the economic situation.
\end{abstract}

Keywords: index analysis, discriminant analysis, multivariate analysis, financial statements of medical units, financial indicators.

JEL: M40, M41

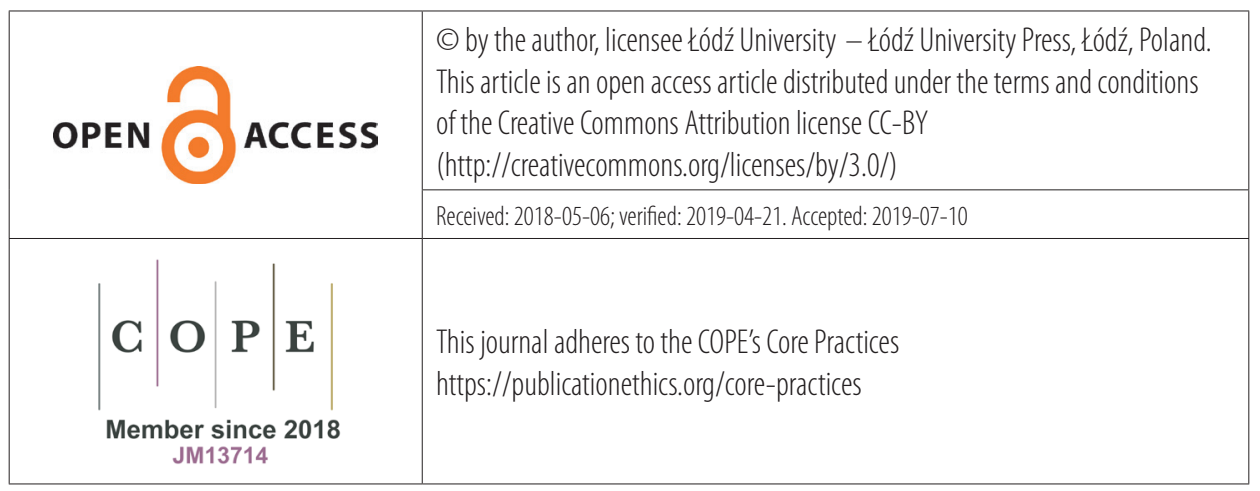

